2014-04

Effects of dietary - $(1,3)(1,6)$-D-glucan supplementation on growth performance, intestinal morphology and haemato-immunological profile of mirror carp (<i>Cyprinus carpio</i $>$ L.)

Kuhlwein, $\mathrm{H}$

http://hdl.handle.net/10026.1/12613

10.1111/jpn.12078

Journal of Animal Physiology and Animal Nutrition

Wiley

All content in PEARL is protected by copyright law. Author manuscripts are made available in accordance with publisher policies. Please cite only the published version using the details provided on the item record or document. In the absence of an open licence (e.g. Creative Commons), permissions for further reuse of content should be sought from the publisher or author. 


\title{
Effects of dietary $\beta$-(1,3)(1,6)-D-glucan supplementation on growth performance, intestinal morphology and haemato-immunological profile of mirror carp (Cyprinus carpio L.)
}

\author{
H. Kühlwein, D. L. Merrifield, M. D. Rawling, A. D. Foey and S. J. Davies \\ Aquatic Animal Nutrition and Health Research Group, School of Biomedical and Biological Sciences, Plymouth University, Plymouth, Devon, UK
}

\section{Summary}

In recent years, aquaculture research has focused on probiotics, prebiotics, and $\beta$-glucans, in order to improve health status and growth performance. Information regarding the effects of $\beta$-glucan on growth performance and intestinal immunity of mirror carp (Cyprinus carpio L.) is scarce. An experiment was therefore conducted to investigate the effects of a yeast $\beta$-glucan preparation (MacroGard ${ }^{\circledR}$ ) on growth performance, intestinal morphology and haemato-immunological indices of mirror carp. Carp (initial weight $11.1 \pm 0.0 \mathrm{~g}$ ) were fed highly purified diets supplemented with $0 \%$ (control), $0.1 \%, 1 \%$ or $2 \%$ MacroGard $^{\circledR}$ for 8 weeks. Fish fed diets containing $1 \%$ and $2 \%$ MacroGard $^{\circledR}$ showed significant improvements in weight gain, specific growth rate and feed conversion ratio compared to fish fed both the control and the $0.1 \%$ MacroGard ${ }^{\circledR}$ containing diet. Histological appraisal of the intestine showed a significantly higher infiltration of leucocytes into the epithelial layer of fish fed diets supplemented with $1 \%$ and $2 \%$ MacroGard $^{\circledR}$ in the anterior intestine compared to fish fed the control and $0.1 \%$ MacroGard ${ }^{\circledR}$ diet. This effect was not observed in the posterior intestine. There were no significant differences in the intestinal absorptive surface area and number of goblet cells in either intestinal region. At the end of the experiment, the haematological status of the fish was examined. Compared to control fed fish, the haematocrit value was significantly elevated in fish fed the $2 \%$ MacroGard ${ }^{\circledR}$ diet. Furthermore, the blood monocyte fraction was significantly higher in fish fed the $1 \%$ and $2 \%$ MacroGard ${ }^{\circledR}$ diets. No significant changes were observed in the other blood parameters assessed. The present study shows that high dietary $\beta$-glucan inclusion increases growth performance without detrimental effects on the health indicators assessed. Increased intraepithelial leucocytes in the anterior intestine may indicate a localized immune response; no detrimental effects on intestinal morphology were observed.

Keywords carp, haematology, histology, gut, health, $\beta$-glucans

Correspondence H. Kühlwein, Aquatic Animal Nutrition and Health Research Group, School of Biomedical and Biological Sciences, Plymouth University, Plymouth, Devon, PL4 8AA, UK. Tel: +44 1752584 877; Fax: +44 1752584 605; E-mail: holger.kuehlwein@plymouth.ac.uk

Received: 24 February 2013; accepted: 27 March 2013

\section{Introduction}

Aquaculture remains the fastest growing agri-business sector with total global production (inland and marine, without aquatic plants) increasing to 63.6 million tonnes in 2011 from 47.3 million tonnes in 2006 (FAO, 2012). On a global scale, cyprinid production is still the prominent sector of freshwater aquaculture (FAO, 2012), accounting for $71.9 \%$ (24.2 million tons) of freshwater production. The intensification of production can lead to increased incidences of stress and disease outbreaks. As a result, a considerable effort has been made to find effective prophylactic measures to support and augment the immune response of fish reared under intensive conditions. Because the EU ratified a ban on non-medical use of antibiotics in animal nutrition in the Regulation (EC) No 1831/2003 (EU, 2003), effective from 2006 onwards, there has been a clear drive towards finding alternative dietary supplements to boost health and production.

Among the most well studied dietary additives are $\beta$-glucans. They are ubiquitous in nature and can be found in the cell walls of yeasts, cereal grains, algae, bacteria and fungi (Zekovic et al., 2005). The most abundant source of natural $\beta$-glucans with highly immunomodulating properties are fungi and yeasts, where research effort has focused in particular on 
$\beta$-(1,3) $(1,6)$-D-glucans. A plethora of information is available regarding their positive effects on growth performance, immune responses and disease resistance upon oral delivery to a number of farmed animals such as swine (Dritz et al., 1995; Li et al., 2006), poultry (Guo et al., 2003; Chen et al., 2008), salmonids (Nikl et al., 1993; Siwicki et al., 1994; Jeney et al., 1997; Lauridsen and Buchmann, 2010) and shellfish (Hai and Fotedar, 2009). For cyprinids, it is also well documented that $\beta$-glucans can enhance the innate immune response and disease resistance (Kwak et al., 2003; Misra et al., 2006; Gopalakannan and Arul, 2010; Siwicki et al., 2010) but to the authors' knowledge the effects on growth performance are scarce.

The aim of the present investigation therefore was to evaluate the efficacy of a commercially available $\beta$ $(1,3)(1,6)$-D-glucan preparation from the yeast Saccharomyces cerevisiae (MacroGard ${ }^{\circledR}$ ) on growth performance, nutrient retention and general haematological indices of mirror carp. As little is known about localized intestinal immune responses in teleosts upon contact of orally administered $\beta$-glucans and the mucus-layer/mucosa, another objective was to examine whether intestinal morphology and intestinal immune response were affected by dietary provision of $\beta$-glucans.

\section{Materials and methods}

Experimental diets

A nutritionally balanced basal diet meeting the known requirements of carp (NRC, 2011) was prepared by TETRA GmbH (Melle, Germany). The main ingredients of the dietary formulation were fish protein concentrate (Soprapeche CPSP 90) containing at least $83 \%$ crude protein and $10 \%$ lipid, and wheat starch (>84\% starch; Table 1). The aim was to produce a highly purified diet to minimize the presence of other ingredients which may influence the local immune response. Four isonitrogenous and isocaloric extruded diets were produced using the basal formulation as the control diet and by supplementing three other diets with $0.1 \%, 1 \%$ and $2 \% \mathrm{~W} / \mathrm{w}$ MacroGard ${ }^{\circledR}$ (Biorigin, Sao Paulo, Brazil) (Table 1). The blended ingredients were extruded to form pellets of $2.5 \mathrm{~mm}$ diameter. Diets were stored in airtight bags at $4{ }^{\circ} \mathrm{C}$ throughout the experiment.

\section{Fish culture and feeding}

The experiment was conducted at the aquarium facilities of the Aquatic Animal Nutrition and Health Research Group, Plymouth University, UK.
Table 1 Formulations (g per $1000 \mathrm{~g}$ ) and chemical composition (\%) of the experimental diets

\begin{tabular}{|c|c|c|c|c|}
\hline Ingredients & Control & $0.1 \% \mathrm{M}$ & $1 \% M$ & $2 \% M$ \\
\hline $\begin{array}{l}\text { Fish protein } \\
\text { concentrate }\end{array}$ & 450.0 & 450.0 & 450.0 & 450.0 \\
\hline Wheat starch & 410.0 & 409.0 & 400.0 & 390.0 \\
\hline Fish oil & 45.0 & 45.0 & 45.0 & 45.0 \\
\hline Soybean oil & 45.0 & 45.0 & 45.0 & 45.0 \\
\hline Cellulose & 25.65 & 25.65 & 25.65 & 25.65 \\
\hline $\begin{array}{l}\text { Min/trace } \\
\text { element } \\
\text { premix* }\end{array}$ & 20.60 & 20.60 & 20.60 & 20.60 \\
\hline Vitamin premix† & 2.50 & 2.50 & 2.50 & 2.50 \\
\hline $\begin{array}{l}\text { Stabilized } \\
\quad \text { vitamin } C \ddagger\end{array}$ & 1.10 & 1.10 & 1.10 & 1.10 \\
\hline Ethoxyquin & 0.15 & 0.15 & 0.15 & 0.15 \\
\hline MacroGard® & 0 & 1 & 10 & 20 \\
\hline \multicolumn{5}{|l|}{$\begin{array}{l}\text { Chemical } \\
\text { composition } \\
\text { (\%DM) }\end{array}$} \\
\hline Dry matter & $92.9 \pm 0.0$ & $95.1 \pm 0.0$ & $94.8 \pm 0.0$ & $95.0 \pm 0.1$ \\
\hline Crude protein & $41.4 \pm 0.1$ & $42.4 \pm 0.3$ & $43.7 \pm 0.3$ & $42.8 \pm 0.2$ \\
\hline Crude lipid§ & $14.2 \pm 0.0$ & $14.5 \pm 0.1$ & $15.0 \pm 0.4$ & $15.1 \pm 0.3$ \\
\hline Ash§ & $4.6 \pm 0.0$ & $4.5 \pm 0.0$ & $4.6 \pm 0.0$ & $4.6 \pm 0.0$ \\
\hline $\begin{array}{l}\text { Gross energy } \\
(\mathrm{MJ} / \mathrm{kg})^{\star \star}\end{array}$ & $22.3 \pm 0.1$ & $22.4 \pm 0.0$ & $22.5 \pm 0.2$ & $22.2 \pm 0.1$ \\
\hline
\end{tabular}

M, MacroGard ${ }^{\circledR}$.

*Mineral/trace element premix per kg feed meal (prior to extrusion): $20.0 \mathrm{~g}$ Mono-calcium phosphate, $10.7 \mathrm{~g}$ Manganese-(II)-sulphate, $5.7 \mathrm{~g}$ Zinc sulphate, $4.1 \mathrm{~g}$ Ferreous-(II)-sulphate, $0.1 \mathrm{~g}$ Cobalt-(II)-acetate. $\dagger$ Vitamin premix per kg feed meal (prior to extrusion): 64800 IU Vitamin A, 2700 IU Vitamin D3, 144 mg Vitamin E, 75.6 mg Vitamin B1, $57.6 \mathrm{mg}$ Vitamin B2, $216 \mathrm{mg}$ Calcium-D-pantothenate, $720 \mathrm{mg}$ Niacin, $29 \mathrm{mg}$ Vitamin B6, $126 \mu \mathrm{g}$ Vitamin B12, 900 mg Inositol, 1134 mg Ascorbic acid.

Min. 35\% Vitamin C activity.

$\S n=3$.

I $n=5$.

$\star * n=2$

Four hundred and fifty mirror carp (Cyprinus carpio L.) were obtained from Hampshire Carp Hatcheries, Hampshire, UK. The fish, weighing approximately $7 \mathrm{~g}$ on average, were carefully acclimatized over 6 weeks whilst being fed the control diet at a rate of $2 \%$ of the bodyweight per day. Thereafter, 25 carp were randomly allocated to each of the twelve 7lL experimental tanks $(n=3$ tanks per treatment). The initial average body weight at the start of the experiment was $11.1 \pm 0.0 \mathrm{~g}$. Twelve of the remaining fish were sampled for analysis of the initial body composition.

The carp were fed $4 \%$ of their body weight (BW) per day by hand at regular intervals (8:30, 11:00, $14: 00 \& 17: 00)$. On the morning of the $6^{\text {th }}$ day $1 \%$ of BW was given to allow a sufficient gastric evacuation period prior to weighing the following day. After 
weighing carp were fed $2 \%$ of BW in the afternoon. The body weight was determined weekly as whole tank body mass.

Water quality was monitored daily and oxygen saturation and $\mathrm{pH}$ were maintained at $89.1 \pm 3.1 \%$ and $6.33 \pm 0.48$, respectively. Ammonium, nitrite and nitrate were determined once a week and the levels ranged between 0 and $0.281 \mathrm{mg} / \mathrm{l}, 0.004-$ $0.084 \mathrm{mg} / \mathrm{l}$ and $8.15-52.92 \mathrm{mg} / \mathrm{l}$, respectively. The average water temperature was maintained at $25 \pm 0.2{ }^{\circ} \mathrm{C}$ with the aid of a heating unit. Mechanical filters were cleaned daily and a partial water exchange (approximately 10\%) was carried out once a week. The photoperiod was maintained at a 12/12h light/dark cycle.

\section{Measurement of growth parameters}

Growth performance and feed utilization were determined as follows:

$$
\text { Body weight }(\mathrm{g})=\frac{\text { total body mass }(\mathrm{g}) \text { per tank }}{\# \text { fish per tank }}
$$

body composition. At the end of the trial, three carp per tank were sampled and pooled together for the final body composition. All samples were analysed according to AOAC protocols (2003). Dry matter (DM) was determined by drying (Gallenkamp Oven BS, OV-160; Gallenkamp, Manchester, UK) at $105{ }^{\circ} \mathrm{C}$ until a constant weight was achieved. The body cavity of the fish samples was opened and the viscera were exposed prior to drying. The dried samples were subsequently homogenized for further analysis. Crude protein ( $\mathrm{N}$ x 6.25, Vapodest 40; Gerhardt Laboratory Instruments, Königswinter, Germany) was measured by automated Kjeldahl method after acid digestion. Crude lipid was determined using the Soxhlet method in the Soxtherm apparatus (model 41x; Gerhardt Laboratory Instruments, Germany). Ash content was determined by incineration at $550{ }^{\circ} \mathrm{C}$ in a muffle furnace (Carbolite ESF3; Carbolite, Hope, UK) for $8 \mathrm{~h}$. Gross energy was measured with a Parr Adiabatic Bomb Calorimeter 1356 (Parr Instrument Company, Moline, IL, USA). The nutrient retention was determined from the initial and final body composition (i.e. protein and energy) using the following formula (where $\mathrm{N}=$ nutrient):

$$
\text { Nutrient retention }=\left(\frac{\left(\frac{\text { final weight }(\mathrm{g})}{100} \times \% \mathrm{~N} \text { final body }-\frac{\text { initial weight }(\mathrm{g})}{100} \times \% \mathrm{~N} \text { initial body }\right)}{\mathrm{N} \text { intake }}\right) \times 100
$$

Weight gain $(\mathrm{g})=$ final weight $(\mathrm{g})$ - initial weight $(g)$

Specific growth rate (SGR)

$$
=\left(\frac{\text { In final weight }- \text { In initial weight }}{\text { experimental period (days) }}\right) \times 100
$$

Feed conversion ratio $(\mathrm{FCR})=\frac{\text { feed intake }(\mathrm{g})}{\text { weight gain }(\mathrm{g})}$

Protein efficiency ratio $(\mathrm{PER})=\frac{\text { weight gain }(\mathrm{g})}{\text { protein intake }(\mathrm{g})}$

\section{Chemical analysis}

Samples of the diets and fish carcasses were taken for gross chemical analysis. At the beginning of the experiment, 12 carp (pooled into four samples) from the initial group of fish were sampled to determine initial

\section{Blood sampling and general haemato-immunological parameters}

At the end of the trial, blood was sampled from five fish per tank $(n=15$ per treatment). The fish were euthanized with tricaine methanesulphonate (MS222; Pharmaq, Fordingbridge, UK), buffered with sodium bicarbonate $\left(\mathrm{NaHCO}_{3}{ }^{-}\right)$, followed by destruction of the brain (PIL № 30/9104 under PPL № 30/2644). Blood was withdrawn immediately from the caudal arch using a $1-\mathrm{ml}$ syringe with a 25-gauge needle and transferred to $1.5-\mathrm{ml}$ microcentrifuge tubes.

\section{Haematocrit}

Blood samples were drawn into heparinised capillary tubes and sealed. The samples were centrifuged at $3600 \mathrm{~g}$ in a microhaematocrit centrifuge (Brown, 1988). After, the percentage packed cell volume (PCV) was read with a Hawksley reader and recorded as percentage of the total blood volume. 


\section{Haemoglobin}

Drabkin's cyanide - ferricyanide solution was used to determine the haemoglobin levels in the blood (Drabkin, 1946). Four $\mu$ l of blood was thoroughly mixed with $1 \mathrm{ml}$ of Drabkin's solution (SigmaAldrich, Dorset, UK) and samples were stored at $4{ }^{\circ} \mathrm{C}$ until further analysis. The haemoglobin contents were then determined by measuring the absorbance at $540 \mathrm{~nm}$ in a spectrophotometer and reading the values against a standard curve (derived from a dilution series from 0 to $180 \mathrm{mg} / \mathrm{l}$ of a cyanmethemoglobin standard).

\section{Total blood cell counts}

Twenty $\mu$ l of the blood samples were thoroughly mixed with $980 \mu \mathrm{l}$ of Dacies solution (equal to a 1:50 dilution) and stored at $4{ }^{\circ} \mathrm{C}$ until further analysis. Total erythrocyte and leucocyte cell counts were determined using a Neubauer haemocytometer.

\section{Differential leucocyte counts}

Blood smears were prepared by using $5 \mu \mathrm{l}$ of blood according to Rowley et al. (1988). The slides were then left to air-dry and fixed in $100 \%$ methanol for 1 min. Smears were then stained with the MayGrünwald-Giemsa (MGG) stain (Biostain Ready Reagents, Cheshire, UK) and rinsed with distilled water. Slides were air-dried at room temperature and mounted with DPX and a cover slip. Two hundred leucocytes per slide were counted and classified according to their morphological appearance into lymphocytes, granulocytes and monocytes.

\section{Serum glucose, total protein and albumin}

In order to obtain serum, whole blood was incubated at $4{ }^{\circ} \mathrm{C}$ for $12 \mathrm{~h}$ in order to allow clotting. After, the samples were centrifuged at $2500 \mathrm{~g}$ for $5 \mathrm{~min}$, the supernatant serum was carefully removed and the serum samples were stored at $-80{ }^{\circ} \mathrm{C}$ until further analysis. The levels of glucose in the serum samples were determined using the glucose oxidase - peroxidase method after Trinder (1969). Total protein levels in serum samples were determined according to the method of Bradford (1976). Albumin levels in serum were determined using the bromocresol green assay by Doumas et al. (1971). The albumin/globulin ratio was also determined for each respective group.

\section{Histology}

For histological appraisal of the intestine at the end of the experiment, 2 fish per tank ( $n=6$ per treatment) were sampled. Intestinal samples of approximately
$1 \mathrm{~cm}$ length were taken from the anterior and posterior intestine and fixed in 10\% formalin for $24 \mathrm{~h}$. Subsequently, samples were dehydrated in graded ethanol concentrations and embedded in paraffin wax. In each specimen, multiple sets of transverse sections ( $5 \mu \mathrm{m}$ thick) were stained with haematoxylin and eosin (H\&E) in order to examine the intestinal perimeter ratio after Dimitroglou et al. (2009). Briefly, the internal perimeter (IP) of the intestinal lumen and the external perimeter (EP) of the intestine were analysed using Image J version 1.42 (National Institute of Health) and the perimeter ratio was calculated $(\mathrm{PR}=\mathrm{IP} / \mathrm{EP}$, arbitrary units, AU). The number of leucocytes (histologically stained cells) infiltrated into the epithelial layer (i.e. intraepithelial leucocytes; IEL's) across a standardized distance of 100 enterocytes (only nucleated cells) was determined as described by Ferguson et al. (2010). In addition, sections were also stained with Alcian blue-PAS (Periodic acid Schiff) in order to differentiate between acid and neutral glycoconjugates and to determine the number of goblet cells in five random mucosal folds per specimen which were then standardized to $100 \mu \mathrm{m}$ of mucosal fold length. For both the leucocyte and the goblet cell counts, the average of the cell numbers from all specimens was calculated.

\section{Statistical analysis}

All presented data are means \pm standard deviation (SD). Data were transformed where necessary. Statistical analysis was performed with SPSS statistics version 18 (SPSS Inc., Chicago, IL, USA). Analysis of normality and homogeneity was performed with the Kolmogorov-Smirnov and Levene test, respectively. The data were subjected to a one-way analysis of variance (ANOvA). Significant differences between control and treatment groups were determined by a post-hoc LSD and significance was accepted at the $\mathrm{p}<0.05$ level.

\section{Results}

\section{Growth performance}

Carp displayed a high growth performance in all groups and no mortalities occurred during the experiment (Table 2). After 8 weeks of feeding, the final body weight increased by over $600 \%$; the weight in groups fed with the $1 \%$ and $2 \%$ MacroGard ${ }^{\circledR}$ supplemented diet $(69.0 \pm 0.7 \mathrm{~g}$ and $66.6 \pm 1.9 \mathrm{~g}$, respectively) was significantly higher than the control $(61.9 \pm 2.4 \mathrm{~g} ; \mathrm{p} \leq 0.009)$ and the $0.1 \%$ Macrogard $^{\circledR}$ group $(63.0 \pm 1.2 \mathrm{~g} ; \mathrm{p} \leq 0.030)$. Consequently, the weight gain of fish fed the $1 \%$ and $2 \%$ Macrogard $^{\circledR}$ 
Table 2 Growth performance of carp after 8 weeks of feeding on experimental diets $(n=3)$

\begin{tabular}{lllll}
\hline & Control & $0.1 \% \mathrm{M}$ & $1 \% \mathrm{M}$ & $2 \% \mathrm{M}$ \\
\hline $\begin{array}{l}\text { Initial } \\
\text { BW (g) }\end{array}$ & $11.1 \pm 0.0$ & $11.2 \pm 0.0$ & $11.1 \pm 0.1$ & $11.2 \pm 0.0$ \\
$\begin{array}{c}\text { Final } \\
\text { BW (g) }\end{array}$ & $61.9 \pm 2.4^{\mathrm{a}}$ & $63.0 \pm 1.2^{\mathrm{a}}$ & $69.0 \pm 0.7^{\mathrm{b}}$ & $66.6 \pm 1.9^{\mathrm{b}}$ \\
Weight & $50.8 \pm 2.5^{\mathrm{a}}$ & $51.8 \pm 1.2^{\mathrm{a}}$ & $57.9 \pm 0.7^{\mathrm{b}}$ & $55.5 \pm 1.9^{\mathrm{b}}$ \\
$\quad$ gain (g) & & & & \\
SGR (\%) & $3.06 \pm 0.07^{\mathrm{a}}$ & $3.09 \pm 0.03^{\mathrm{a}}$ & $3.26 \pm 0.02^{\mathrm{b}}$ & $3.19 \pm 0.05^{\mathrm{b}}$ \\
FCR (g/g) & $0.90 \pm 0.02^{\mathrm{ab}}$ & $0.92 \pm 0.01^{\mathrm{a}}$ & $0.86 \pm 0.01^{\mathrm{c}}$ & $0.88 \pm 0.02^{\mathrm{b}}$ \\
PER (g/g) & $2.48 \pm 0.05$ & $2.45 \pm 0.02$ & $2.53 \pm 0.02$ & $2.51 \pm 0.04$ \\
\hline
\end{tabular}

M, MacroGard ${ }^{\oplus}$; BW, body weight; FCR, feed conversion ratio; SGR, specific growth rate; PER, protein efficiency ratio.

${ }^{a b c}$ Different superscript letters indicate a significant difference $(p<0.05)$

Table 3 Initial $(n=4)$ and final $(n=3)$ body composition of carp

\begin{tabular}{llllll}
\hline & Initial & Control & $0.1 \% \mathrm{M}$ & $1 \% \mathrm{M}$ & $2 \% \mathrm{M}$ \\
\hline $\begin{array}{c}\text { Moisture } \\
(\%)\end{array}$ & $77.4 \pm 0.4$ & $72.7 \pm 0.3$ & $72.5 \pm 0.4$ & $73.0 \pm 0.6$ & $72.9 \pm 0.3$ \\
$\begin{array}{c}\text { Protein } \\
(\%)\end{array}$ & $14.8 \pm 0.1$ & $15.1 \pm 0.4$ & $15.3 \pm 0.3$ & $15.0 \pm 0.5$ & $15.3 \pm 0.4$ \\
Fat (\%) & $4.8 \pm 0.5$ & $9.3 \pm 0.3$ & $9.5 \pm 0.3$ & $8.9 \pm 0.5$ & $9.2 \pm 0.3$ \\
Ash (\%) & $3.3 \pm 0.1$ & $2.4 \pm 0.1$ & $2.4 \pm 0.2$ & $2.4 \pm 0.1$ & $2.4 \pm 0.1$ \\
$\begin{array}{c}\text { Energy } \\
\text { (MJ/kg) }\end{array}$ & $5.2 \pm 0.2$ & $6.7 \pm 0.1$ & $6.6 \pm 0.2$ & $6.7 \pm 0.2$ & $6.7 \pm 0.1$ \\
\hline
\end{tabular}

M, MacroGard ${ }^{\circledR}$.

supplemented diets was significantly higher. The same was observed for the specific growth rates (SGR) where fish fed the $1 \%(3.26 \pm 0.02 \%)$ and $2 \%$ $(3.19 \pm 0.05 \%)$ Macrogard ${ }^{\circledR}$ supplemented diet displayed an increased SGR compared to fish fed the control $(3.06 \pm 0.07 \%)$ and the $0.1 \%$ Macrogard $^{\circledR}$ $(3.09 \pm 0.03 \%)$ supplemented diet. This is also reflected in a better feed conversion with the $1 \%$ group showing the lowest feed conversion ratio (FCR) of $0.86 \pm 0.01$, which was significantly superior to all other groups $(p \leq 0.029)$. Fish from the $2 \%$ group displayed significantly better FCR than the $0.1 \%$ group $(\mathrm{p}=0.012)$ and a trend towards a lower FCR compared to the control group $(\mathrm{p}=0.078)$. The protein utilization was unaffected by dietary treatment.

\section{Proximate composition of fish carcasses and nutrient retention}

Table 3 shows the body composition of the carp at the beginning and at the end of the experiment. No significant differences were seen in any of the parameters between control and treatment groups at the end of the trial. Dietary protein was retained at levels of $47-49 \%$ and energy at $39-41 \%$. There were no significant differences between treatments (data not shown).

\section{Haemato-immunological parameters}

The haemato-immunological parameters are presented in Table 4. Significant differences in haematocrit levels (\%PCV) were observed between the groups. Fish fed the $2 \%$ MacroGard $^{\circledR}$ diet displayed higher\% PCV $(47.5 \pm 3.3 \%)$ when compared to fish fed the control and $0.1 \%$ MacroGard ${ }^{\circledR}$ diets. Haemoglobin levels remained unaffected by MacroGard ${ }^{\circledR}$ supplementation, and therefore, the mean corpuscular haemoglobin concentration (MCHC) was significantly lower in the $2 \%$ MacroGard $^{\circledR}$ fed group $(18.8 \pm 1.4 \%)$. Furthermore, fish fed the $1 \%$ and $2 \%$ MacroGard ${ }^{\circledR}$ supplemented diets showed significantly elevated levels of monocytes $(3.7 \pm 1.8 \%$ and $3.0 \pm 1.4 \%$, respectively) in the peripheral blood compared to the control group ( $1.6 \pm 0.8 \%$; Table 5$)$.
Table 4 Haemato-immunological parameters after the 8-week feeding period ( $n=15)$

\begin{tabular}{lcccc}
\hline & Control & $0.1 \% \mathrm{M}$ & $1 \% \mathrm{M}$ & $2 \% \mathrm{M}$ \\
\hline Haematocrit (\%) & $42.8 \pm 4.0^{\mathrm{a}}$ & $42.2 \pm 2.6^{\mathrm{a}}$ & $45.2 \pm 5.9^{\mathrm{ab}}$ & $47.5 \pm 3.3^{\mathrm{b}}$ \\
MCHC (\%) & $22.2 \pm 3.3^{\mathrm{a}}$ & $22.4 \pm 2.0^{\mathrm{a}}$ & $20.2 \pm 4.5^{\mathrm{ab}}$ & $18.8 \pm 1.4^{\mathrm{b}}$ \\
MCV (fL) & $317.9 \pm 60.9$ & $309.8 \pm 61.0$ & $333.4 \pm 53.1$ & $332.7 \pm 67.9$ \\
Haemoglobin(g/dl) & $9.4 \pm 0.8$ & $9.6 \pm 0.8$ & $9.3 \pm 1.3$ & $9.0 \pm 0.6$ \\
RBC $\left(\times 10^{6} / \mathrm{ml}\right)$ & $1.37 \pm 0.19$ & $1.44 \pm 0.33$ & $1.37 \pm 0.17$ & $1.47 \pm 0.25$ \\
WBC $\left(\times 10^{4} / \mathrm{ml}\right)$ & $2.97 \pm 0.71$ & $3.24 \pm 1.10$ & $3.39 \pm 0.76$ & $3.06 \pm 0.58$ \\
Glucose $(\mathrm{mm})$ & $3.2 \pm 0.7$ & $2.7 \pm 0.8$ & $3.5 \pm 1.1$ & $3.2 \pm 0.7$ \\
Serum protein $(\mathrm{g} / \mathrm{dl})$ & $2.91 \pm 0.2$ & $3.37 \pm 0.47$ & $3.15 \pm 0.47$ & $3.25 \pm 0.32$ \\
Serum albumin (g/dl) & $1.08 \pm 0.12$ & $1.09 \pm 0.07$ & $1.12 \pm 0.11$ & $1.10 \pm 0.09$ \\
Serum globulin (g/dl) & $1.84 \pm 0.25$ & $2.21 \pm 0.48$ & $2.08 \pm 0.44$ & $2.15 \pm 0.31$ \\
Albumin/globulin & $0.60 \pm 0.14$ & $0.52 \pm 0.11$ & $0.57 \pm 0.14$ & $0.52 \pm 0.09$ \\
\hline
\end{tabular}

M, MacroGard ${ }^{\circledR}$; MCHC, mean corpuscular haemoglobin concentration; MCV, mean corpuscular volume; RBC, red blood cells; WBC, white blood cells.

${ }^{\mathrm{ab}}$ Different superscript letters indicate a significant difference $(p<0.05)$. 
Table 5 Differential leucocyte cell counts (\%) in the peripheral blood of carp after the 8-week feeding period $(n=15)$

\begin{tabular}{lcccc}
\hline & Control & \multicolumn{1}{l}{$0.1 \% \mathrm{M}$} & \multicolumn{1}{l}{$1 \% \mathrm{M}$} & \multicolumn{1}{l}{$2 \% \mathrm{M}$} \\
\hline Lymphocytes (\%) & $89.9 \pm 4.8$ & $88.7 \pm 5.8$ & $87.5 \pm 4.9$ & $89.1 \pm 3.8$ \\
Granulocytes (\%) & $8.5 \pm 4.6$ & $8.8 \pm 5.9$ & $8.8 \pm 4.7$ & $7.9 \pm 3.3$ \\
Monocytes (\%) & $1.6 \pm 0.8^{\mathrm{a}}$ & $2.5 \pm 1.2^{\mathrm{ab}}$ & $3.7 \pm 1.8^{\mathrm{c}}$ & $3.0 \pm 1.4^{\mathrm{bc}}$ \\
\hline
\end{tabular}

M, MacroGard ${ }^{\circledR}$

${ }^{a b c}$ Different superscript letters indicate a significant difference $(p<0.05)$.

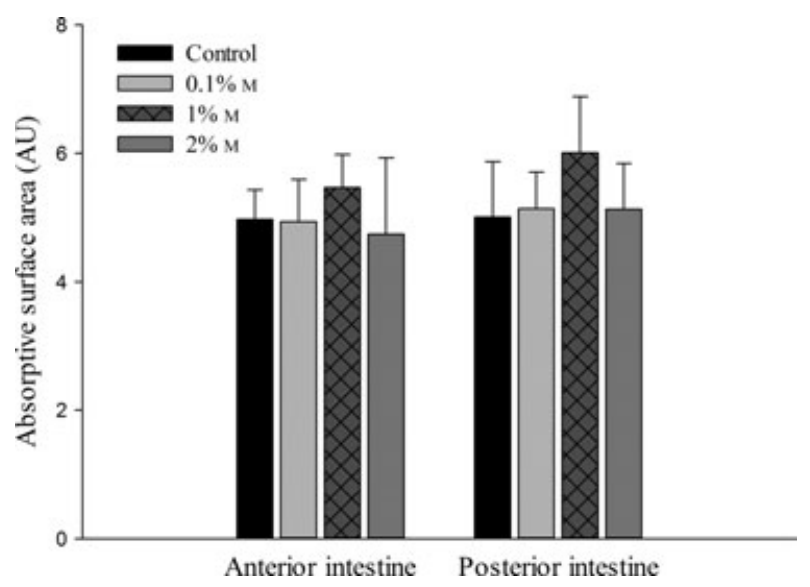

Fig. 1 Mean ( $\pm S D$ ) absorptive surface area (arbitrary units) in anterior and posterior intestine after the 8-week feeding period $(n=6)$.

The other parameters were not significantly different between dietary treatments.

\section{Intestinal histology}

Light microscopy revealed a normal arrangement of columnar enterocyte cells, with an apical microvilli brush border, forming the epithelium of the mucosal folds. No pathological lesions or necrotic cells were observed in any of the fish sampled from each treatment group. Acidic mucosubstances were almost exclusively predominant in the goblet cells and in the mucus covering the brush border. There were no significant differences between treatment groups with regards to the absorptive surface area (Fig. 1) or the number of goblet cells in the epithelium in either anterior or posterior intestinal sections (Figs 2 and 3). However, a trend towards elevated goblet cell levels was evident in the anterior intestine with MacroGard $^{\circledR}$ supplementation $(p<0.064)$. A significantly higher number of intraepithelial leucocytes (IEL's) was observed in the anterior intestine of fish fed the $1 \%$ and $2 \%$ MacroGard $^{\circledR}$ supplemented diets compared to fish fed the control and the $0.1 \%$ MacroGard $^{\circledR}$ containing diet ( $<0.05$; Figs 4 and 5).

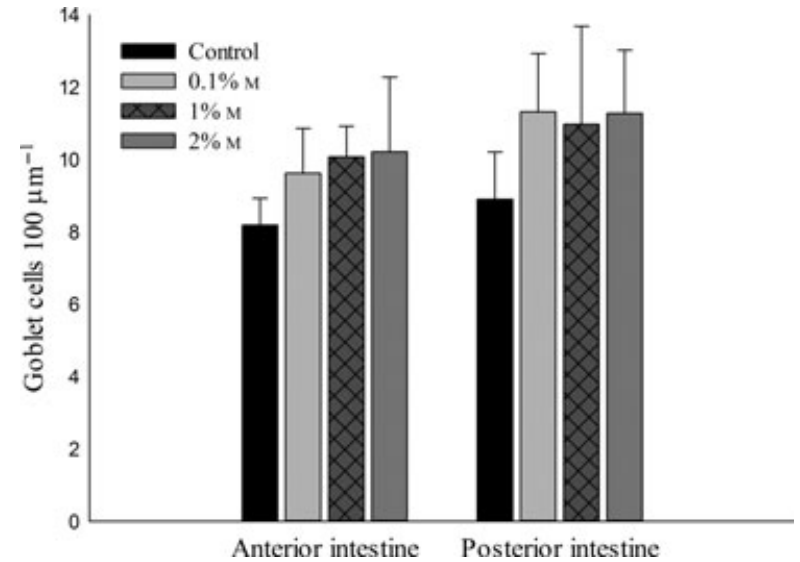

Fig. 2 Mean $( \pm S D)$ number of goblet cells per $100 \mu m$ in anterior and posterior intestine after the 8-week feeding period $(n=6)$.

\section{Discussion}

The findings of the present study indicate that high dietary levels of MacroGard ${ }^{\circledR}(1 \%$ and $2 \%)$ promote enhanced weight gain, specific growth rates and better feed conversion of mirror carp, whereas a low level of $0.1 \%$ MacroGard $^{\circledR}$ did not show such an effect. Growth enhancing effects of $\beta$-glucans in mirror carp have not been reported previously to the authors' knowledge but superior weight gain and specific growth rates were reported recently in koi carp (Cyprinus carpio koi) fed $\beta$-glucan (from S. cerevisiae) at a level of $0.09 \%$, to apparent satiation, for 56 days (Lin et al., 2011). Misra et al. (2006) reported higher specific growth rates after 56 days in the cyprinid rohu (Labeo rohita) fed a diet containing comparatively low doses $(0.025 \%$ and $0.05 \%)$ of a barley derived $\beta$-glucan at a rate of $3 \%$ of the body weight per day. Similarly, a S. cerevisiae derived $\beta$-(1,3)-glucan fed to apparent satiation for 56 days to large yellow croaker (Pseudosciaena crocea) had positive effects on growth performance at $0.09 \%$ dietary inclusion, but not at $0.18 \%$ inclusion (Ai et al., 2007). Other studies have not observed growth enhancing properties when feeding $\beta$-glucans to Nile tilapia (Oreochromis niloticus) (Shelby et al., 2009), channel catfish (Ictalurus punctatus) (Welker et al., 2007), European sea bass (Dicentrarchus labrax) (Bagni et al., 2005) or hybrid striped bass (Morone chrysops X Morone saxatilis) (Li et al., 2009). In the present study, whole body chemical composition, protein retention and energy retention remained unaffected by dietary $\beta$-glucan inclusion indicating that the enhanced growth performance with $1 \%$ and $2 \%$ MacroGard $^{\circledR}$ supplementation was not caused by a higher retention of these nutrients. 

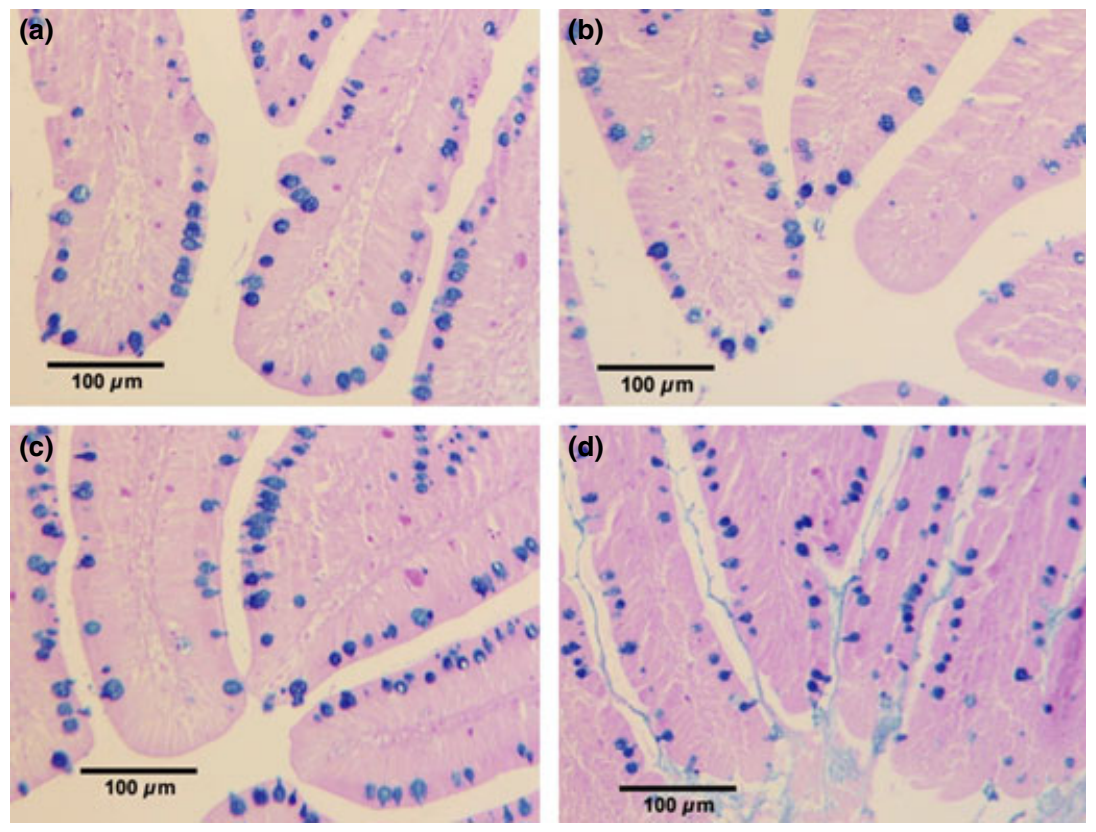

Fig. 3 Transverse sections of the anterior intestine of carp after the 8-week feeding period stained with Alcian blue-PAS visualizing the glycoconjugates within the goblet cells; $a=$ control diet, $b=0.1 \%$ MacroGard $^{\boxplus}, c=1 \%$ Macrogard $^{\boxplus}$ and $d=2 \%$ Macrogard $^{\boxplus}$ supplemented diets. Scale bar represents $100 \mu \mathrm{m}$.

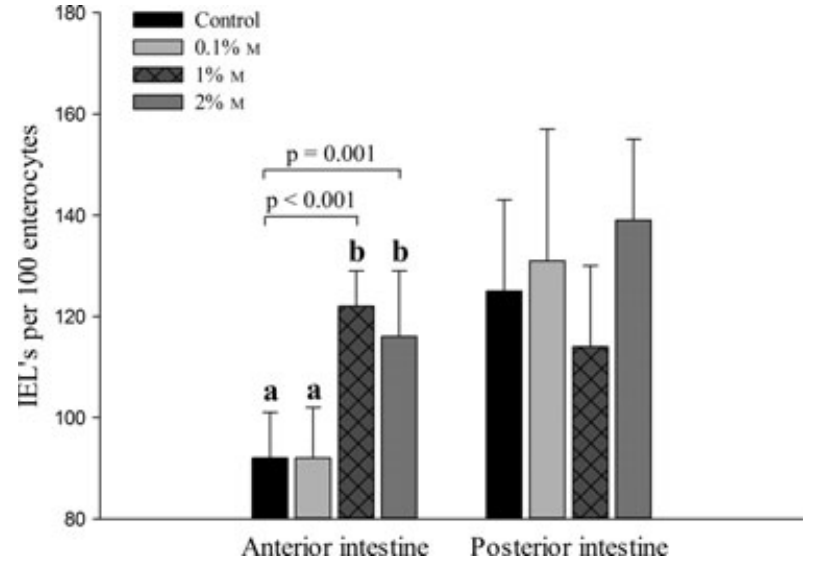

Fig. 4 Mean $( \pm S D)$ infiltration of intraepithelial leucocytes (IEL's) per 100 enterocytes in the anterior (Al) and posterior (PI) intestine after the 8-week period $(n=6) ;{ }^{a b}$ different letters indicate a significant difference between fish fed the $1 \%$ and $2 \%$ MacroGard ${ }^{\circledR}$ supplemented diet compared to fish fed the control and $0.1 \%$ Macrogard $^{\circledR}$ supplemented diet in the anterior intestine $(p<0.05)$; diet code: $M=$ MacroGard $^{\circledR}$.

At present, it is not clear what causes the improvements in growth observed with dietary $\beta$-glucans in previous studies and it is not clear why growth enhancing effects of $\beta$-glucans occur in some aquatic species and not in others. However, Dalmo and Bøgwald (2008) suggested that the effects may depend on the concentration of the $\beta$-glucan in the diet, its solubility, the fish species, the water temperature and length of the feeding period. They also hypothesize, when growth enhancing effects occur that the $\beta$-glucans induce a localized intestinal immune response that in turn leads to resistance against pathogens which otherwise would cause reduced weight gain and possibly disease.

However, histology derived data on the effects of $\beta$ glucans on the intestine and its associated lymphoid tissues are scarce, but data derived from the present study may help to support this hypothesis. High dietary inclusion levels ( $1 \%$ and $2 \%$ ) of MacroGard ${ }^{\circledR}$ in the present study caused increased infiltration of leucocytes from the lamina propria into the epithelial layer (i.e. IEL's) in the anterior intestine, whereas the low inclusion of $0.1 \%$ MacroGard $^{\circledR}$ had no such effect. Similar findings have been reported in mice; Tsukada et al. (2003) reported that mice receiving $25 \mathrm{mg}$ of a $\beta$-(1,3)(1,6)-D-glucan per day displayed elevated intraepithelial lymphocytes in the small intestine. The lower $\beta$-glucan dosage (10 mg) decreased the number, whereas doubling the dosage (50 mg) yielded a similar amount of intraepithelial lymphocytes compared to the $\beta$-glucan dosage of $25 \mathrm{mg}$. Shen et al. (2007) reported similar findings in their mice studies. In the present study, dietary $1 \%$ and $2 \%$ Macrogard $^{\circledR}$ supplementations significantly elevated the monocyte proportion of the peripheral blood leucocytes. Monocytes are key components of the innate immune response and respond quickly to sites of inflammation 

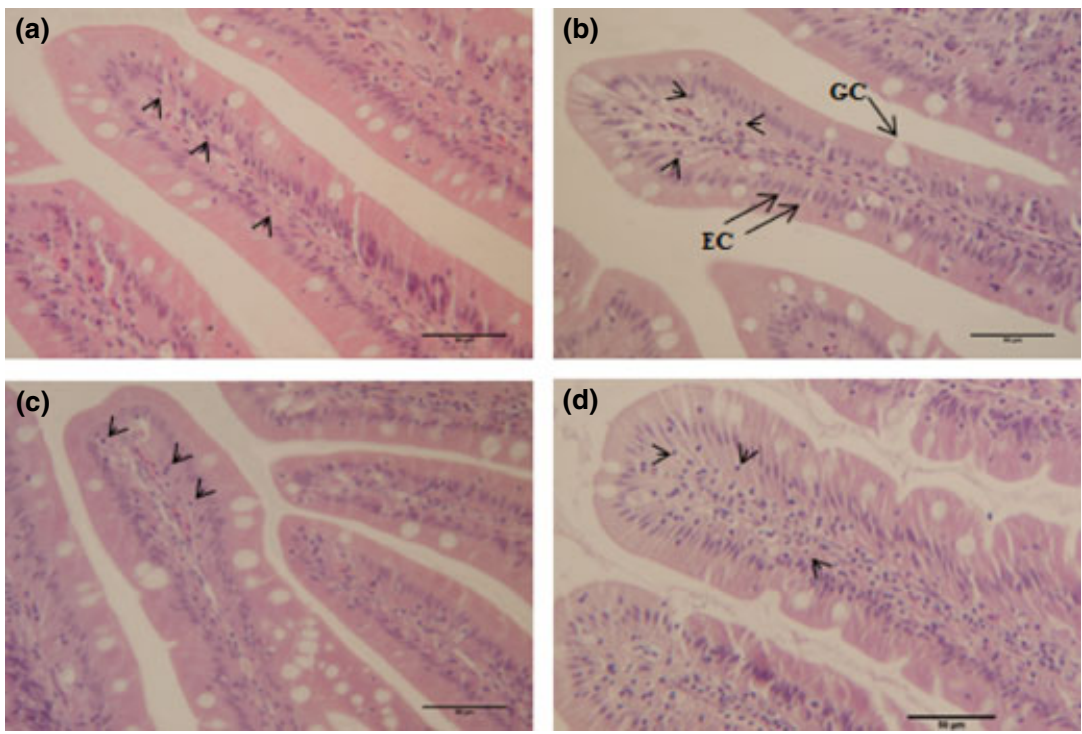

Fig. 5 Transverse sections of the anterior intestine of carp after the 8-week feeding period stained with H\&E showing leucocytes (arrowheads) infiltrating from the lamina propria into the epithelial layer ( $E C=$ enterocytes; $G C=$ goblet cells; exemplary shown in $B$ ); $a=c o n t r o l$ diet, $b=0.1 \%$

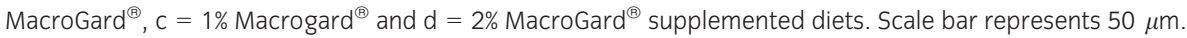

to replenish macrophage and dendritic populations (Gordon and Taylor, 2005; Shi and Pamer, 2011). The evaluation in the present study might be indicative of their transport to the anterior epithelium to bolster and replenish localized IEL levels. Further studies, such as the immunohistochemistry and the analysis of mucosal cytokines, are required to validate this hypothesis because it has recently been shown that orally administered $\beta$-glucans may down-regulate the gene expression of pro-inflammatory cytokines in carp intestine (Falco et al., 2012) and in rainbow trout spleen (Djordjevic et al., 2009). Even though absorption and pharmacokinetics of $\beta$-glucans in the teleost gastrointestinal tract are not known yet, it is possible that the different responses of the anterior and posterior intestinal regions might be due to differences in the $\beta$-glucan levels present in the intestinal regions. It is possible that $\beta$-glucans could be internalized by macrophages through phagocytic processes (Chan et al., 2009) as has been shown for soluble $\beta$-glucans in rats (Rice et al., 2005) and for particulate $\beta$-glucans in mice (Hong et al., 2004) or fermentative processes by the microbiota in the complex intestinal ecosystem (e.g. through $\beta$-glucanase activity (Chen and Seviour, 2007)) may reduce the level, or change the structure, of the $\beta$-glucans that reach the posterior intestine. Future research is warranted to test this hypothesis.

Histological analysis also revealed that the mucus composition in the goblet cells consisted predominantly of acid mucus which is consistent with the findings of Ngamkala et al. (2010) who administered
$1 \%$ dietary $\beta$-glucan to Nile tilapia for 2 weeks prior to a challenge with Aeromonas hydrophila. The total number of goblet cells in the anterior intestine with high $\beta$-glucan supplementation in the present study was not significantly different from the control group, but a trend towards elevation was evident. Ngamkala et al. (2010) did not observe corresponding changes in anterior or posterior intestine in their study. This could be related to species-specific differences, the shorter administration of $\beta$-glucan over 2 weeks and/ or the type of $\beta$-glucan used (sonicated curdlan, a linear bacterial $\beta$-glucan). Zhu et al. (2012), however, reported an increase of intestinal goblet cells in their study of channel catfish fed diets supplemented with a S. cerevisiae yeast polysaccharide mixture (containing $\beta$-(1,3) $(1,6)$-D-glucan and mannan oligosaccharides) for 7 weeks. Unfortunately, the authors do not state exactly which intestinal region they sampled. The mucus produced and released by the goblet cells forms a layer covering the epidermal body surfaces (including the intestinal epithelium) and constitutes, among other functions, the first line of defence against external influences (Shephard, 1994). The mucus layer builds a trap for particles, bacteria and viruses, thereby hindering translocation to the internal environment, and subsequently the intestinal peristaltic processes expel those potentially pathogenic organisms (Mayer, 2003). It is therefore likely that an elevated number of goblet cells lead to a higher release of mucus in the intestine, therefore improving first line of defence mechanisms. 
The absorptive surface area, as determined by the internal/external surface area ratio, was not affected by the dietary treatments in the present study. However, using scanning electron microscopy, Hai and Fotedar (2009) reported increased surface structures (larger upper folds) of the intestines of western king prawns after 6 and 12 weeks of dietary supplementation of $\beta$-glucan. Studies with broiler chickens showed that supplemented yeast cell wall fractions from $S$. cerevisiae, as well as its main structural components $\beta$-glucan and mannoproteins, equally led to higher villus length in the jejunum (Morales-López et al., 2009). The same group observed in a similar subsequent study that the same yeast cell wall fraction increased villus height, mucus thickness and number of goblet cells without changing the ileal content viscosity (MoralesLópez et al., 2010). A number of studies focusing on mannan oligosaccharides (MOS) derived from S. cerevisiae showed enhancing effects on gut morphology (absorptive surface area) and ultrastructure (microvilli length and density) in rainbow trout (Dimitroglou et al., 2009) and sea bream (Dimitroglou et al., 2010), whereas effects on gut histology were absent in European sea bass (Torrecillas et al., 2007).

As haematological and biochemical indices are recognized as a useful means to assess health status and physiological response of an organism towards nutritional and environmental changes (Schütt et al., 1997; Cnaani et al., 2004; Jawad et al., 2004), the present study investigated a number of haematoimmunological parameters. Fish fed MacroGard ${ }^{\circledR}$ supplemented diets did not show significantly altered circulatory leucocyte cell counts, erythrocyte cell counts, serum glucose concentration, serum total protein, serum albumin or globulin levels or albumin/globulin ratio after 8 weeks. These findings are broadly in accordance with the study of Misra et al. (2006), who observed no effect on rohu serum total protein, serum albumin or globulin levels or albumin/globulin ratio after 8 weeks of feeding. However, some differences in these parameters were observed at earlier time points and glucose levels were reduced and peripheral leucocyte levels were elevated at 8 weeks. Peripheral leucocyte levels were also reported to be elevated in koi carp after 8 weeks feeding of $0.09 \%$ of a S. cerevisiae $\beta$-glucan (Lin et al., 2011). Feeding tench (Tinca tinca) with MacroGard ${ }^{\circledR}(0.1$ and $0.2 \%)$ led to higher serum globulin levels after 4 weeks, but serum total protein was not affected (Siwicki et al., 2010). A previous study reported that MacroGard ${ }^{\circledR}$ and other immunostimulants enhanced both parameters in rainbow trout after 1 week of feeding (Siwicki et al., 1994).
In the present study, haematocrit levels were significantly elevated in carp fed the $2 \%$ MacroGard ${ }^{\circledR}$ supplemented diet. The haemoglobin levels were unaffected by dietary $\beta$-glucan, and thus, the MCHC levels were correspondingly lower in the same group. Increased haematocrit levels have been observed in Channel catfish fed diets supplemented with $0.1 \%$ dietary MacroGard $^{\circledR}$ for 4 weeks with no effect on haemoglobin concentration (Welker et al., 2007). Babíček et al. (2007) reported increased haematocrit levels in rats fed a $\beta$ - $(1,3)(1,6)$-D-glucan from $S$. cerevisiae. Higher haematocrit and haemoglobin levels were reported in Nile tilapia upon administration of high levels $(0.1 \%$ to $0.5 \%$ ) of baker's yeast S. cerevisiae (Abdel-Tawwab et al., 2008). Other studies did not observe any changes in haematocrit levels, for example, in spotted rose snapper (Lutjanus guttatus) (Del Rio-Zaragoza et al., 2011) or rainbow trout (Siwicki et al., 1994).

\section{Conclusions}

The current study demonstrates that high dietary inclusion levels of $\beta$-glucan can enhance growth performance and localized intestinal leucocyte infiltration in the anterior intestine of mirror carp without detrimental effects on carcass composition, intestinal morphology or the haemato-immunological parameters investigated. However, future research is needed in order to further investigate the underlying reasons for the growth promoting effects. Furthermore, detailed studies (e.g. using immunohistochemistry, gene expression and proteomics) of the localized immunity at the mucosal level are required to explore the mechanisms and reasons for the increased IEL's found in the present study. Future studies are also recommended to assess the gastrointestinal microbiota which could either be affected directly by selective utilization of $\beta$-glucans by certain bacterial groups, or secondarily by changes in the host's localized immune status. Possible changes could alter the microbial balance which in turn might influence the host immunity or $\beta$-glucan availability.

\section{Acknowledgements}

The authors wish to thank Ben Eynon, Liz Preston, Matthew Emery and Andrew Atfield for their technical support. Also the provision of MacroGard ${ }^{\circledR}$ (Biorigin) and the diets (Tetra $\mathrm{GmbH}$ ) was highly appreciated. The research leading to these results has received funding from the European Community's Seventh Framework Programme [FP7/2007-2013] under grant agreement no. PITN-GA-2008-214505. 


\section{References}

Abdel-Tawwab, M.; Abdel-Rahman, A. M.; Ismael, N. E. M., 2008: Evaluation of commercial live bakers' yeast, Saccharomyces cerevisiae as a growth and immunity promoter for Fry Nile tilapia, Oreochromis niloticus (L.) challenged in situ with Aeromonas hydrophila. Aquaculture 280, 185-189.

Ai, Q.; Mai, K.; Zhang, L.; Tan, B.; Zhang, W.; Xu, W.; Li, H., 2007: Effects of dietary beta-1,3 glucan on innate immune response of large yellow croaker, $P s e u-$ dosciaena crocea. Fish $\theta$ Shellfish Immunology 22, 394-402.

AOAC 2003: Official methods of analysis. In: H. Horwitz (ed.), Official methods of analysis of the association of Official analytical chemists. Association of Official Analytical Chemists Inc, Arlington, VA, pp. 2200.

Babíček, K.; Čechová, I.; Simon, R. R.; Harwood, M.; Cox, D. J., 2007: Toxicological assessment of a particulate yeast $(1,3 / 1,6)$ - $\beta$-d-glucan in rats. Food and Chemical Toxicology 45, 1719-1730.

Bagni, M.; Romano, N.; Finoia, M. G.; Abelli, L.; Scapigliati, G.; Tiscar, P. G.; Sarti, M.; Marino, G., 2005: Shortand long-term effects of a dietary yeast beta-glucan (Macrogard) and alginic acid (Ergosan) preparation on immune response in sea bass (Dicentrarchus labrax). Fish $\theta$ Shellfish Immunology $\mathbf{1 8}$, 311-325.

Bradford, M. M., 1976: A rapid and sensitive method for the quantitation of microgram quantities of protein utilizing the principle of protein-dye binding. Analytical Biochemistry 72, 248-254.

Brown, B. A., 1988: Routine Haematology Procedures. Leo and Febiger, Philadelphia.

Chan, G.; Chan, W.; Sze, D., 2009: The effects of beta-glucan on human immune and cancer cells. Journal of Hematology $\theta$ Oncology 2, 25.

Chen, J.; Seviour, R., 2007: Medicinal importance of fungal $\beta$-(1 $\rightarrow 3),(1 \rightarrow 6)$ glucans. Mycological Research 111, 635652.

Chen, K.-L.; Weng, B.-C.; Chang, M.-T.; Liao, Y.-H.; Chen, T.-T.; Chu, C., 2008: Direct enhancement of the phagocytic and bactericidal Capability of abdominal macrophage of chicks by $\beta$-1,3-1,6-glucan. Poultry Science 87, 2242-2249.
Cnaani, A.; Tinman, S.; Avidar, Y.; Ron, M.; Hulata, G., 2004: Comparative study of biochemical parameters in response to stress in Oreochromis aureus, O. mossambicus and two strains of $O$. niloticus. Aquaculture Research 35, 1434-1440.

Dalmo, R. A.; Bøgwald, J., 2008: ß-glucans as conductors of immune symphonies. Fish $\theta$ Shellfish Immunology 25, 384-396. Del Rio-Zaragoza, O. B.; Fajer-ÁVila, E. J.; AlmazÁN-Rueda, P., 2011: Influence of $\beta$-glucan on innate immunity and resistance of Lutjanus guttatus to an experimental infection of dactylogyrid monogeneans. Parasite Immunology 33. 483-494.

Dimitroglou, A.; Merrifield, D. L.; Moate, R.; Davies, S. J.; Spring, P.; Sweetman, J.; Bradley, G., 2009: Dietary mannan oligosaccharide supplementation modulates intestinal microbial ecology and improves gut morphology of rainbow trout, Oncorhynchus mykiss (Walbaum). Journal of Animal Science 87, 32263234.

Dimitroglou, A.; Merrifield, D. L.; Spring, P.; Sweetman, J.; Moate, R.; Davies, S. J., 2010: Effects of mannan oligosaccharide (MOS) supplementation on growth performance, feed utilisation, intestinal histology and gut microbiota of gilthead sea bream (Sparus aurata). Aquaculture 300, 182-188.

Djordjevic, B.; Skugor, S.; Jorgensen, S. M.; Overland, M.; Mydland, L. T.; Krasnov, A., 2009: Modulation of splenic immune responses to bacterial lipopolysaccharide in rainbow trout (Oncorhynchus mykiss) fed lentinan, a beta-glucan from mushroom Lentinula edodes. Fish $\theta$ Shellfish Immunology 26, 201-209.

Doumas, B. T.; Ard Watson, W.; Biggs, H. G., 1971: Albumin standards and the measurement of serum albumin with bromcresol green. Clinica Chimica Acta 31, 87-96.

Drabkin, D. L., 1946: Spectrophotometric studies XIV. The crystallographic and optical properties of the hemoglobin of man in comparison with those of other species. Journal of Biological Chemistry 164, 703-723.

Dritz, S. S.; Shi, J.; Kielian, T. L.; Goodband, R. D.; Nelssen, J. L.; Tokach, M. D.; Chengappa, M. M.; Smith, J. E.; Blecha, F., 1995: Influence of dietary beta-glucan on growth performance, nonspecific immunity, and resistance to
Streptococcus suis infection in weanling pigs. Journal of Animal Science 73, 33413350.

EU 2003: Regulation (EC) No 1831/2003 of the European Parliament and of the Council of 22 September 2003 on additives for use in animal nutrition. The European Parliament and the Council of the European Union.

Falco, A.; Frost, P.; Miest, J.; Pionnier, N.; Irnazarow, I.; Hoole, D., 2012: Reduced inflammatory response to Aeromonas salmonicida infection in common carp (Cyprinus carpio L.) fed with $\beta$-glucan supplements. Fish and Shellfish Immunology 32, 1051-1057.

FAO 2012: The State of World Fisheries and Aquaculture 2010.

Ferguson, R. M. W.; Merrifield, D. L.; Harper, G. M.; Rawling, M. D.; Mustafa, S.; Picchietti, S.; Balcázar, J. L.; Davies, S. J., 2010: The effect of Pediococcus acidilactici on the gut microbiota and immune status of on-growing red tilapia (Oreochromis niloticus). Journal of Applied Microbiology 109, 851-862.

Gopalakannan, A.; Arul, V., 2010: Enhancement of the innate immune system and disease-resistant activity in Cyprinus carpio by oral administration of beta-glucan and whole cell yeast. Aquaculture Research 40, 884-892.

Gordon, S.; Taylor, P. R., 2005: Monocyte and macrophage heterogeneity. Nature Reviews Immunology 5, 953-964.

Guo, Y.; Ali, R. A.; Qureshi, M. A., 2003: The influence of $\beta$-glucan on immune responses in broiler chicks. Immunopharmacology and Immunotoxicology 25, 461472.

Hai, N. V.; Fotedar, R., 2009: Comparison of the effects of the prebiotics (Bio-Mos ${ }^{\circledR}$ and $\beta$-1,3-D-glucan) and the customised probiotics (Pseudomonas synxantha and $P$. aeruginosa) on the culture of juvenile western king prawns (Penaeus latisulcatus Kishinouye, 1896). Aquaculture 289, 310-316.

Hong, F.; Yan, J.; Baran, J. T.; Allendorf, D. J.; Hansen, R. D.; Ostroff, G. R.; Xing, P. X.; Cheung, N.-K. V.; Ross, G. D., 2004: Mechanism by which orally administered $\beta$-1,3-glucans enhance the tumoricidal activity of antitumor monoclonal antibodies in murine tumor models. The Journal of Immunology 173, 797-806.

Jawad, L. A.; Al-Mukhtar, M. A.; Ahmed, H. K., 2004: The relationship between 
haematocrit and some biological parameters of the Indian shad, Tenualosa ilisha (Family Clupeidae). Animal Biodiversity and Conservation 27, 47-52.

Jeney, G.; Galeotti, M.; Volpatti, D.; Jeney, Z.; Anderson, D. P., 1997: Prevention of stress in rainbow trout (Oncorhynchus mykiss) fed diets containing different doses of glucan. Aquaculture 154, 1-15.

Kwak, J. K.; Park, S. W.; Koo, J. G.; Cho, M. G.; Buchholz, R.; Goetz, P., 2003: Enhancement of the non-specific defence activities in carp (Cyprinus carpio) and flounder (Paralichthys olivcaces) by oral administration of schizophyllan. Acta Biotechnologica 23, 359-371.

Lauridsen, J. H.; Buchmann, K., 2010: Effects of short- and long-term glucan feeding of rainbow trout (Salmonidae) on the susceptibility to Ichthyophthirius multifiliis infections. Acta Ichthyologica Et Piscatoria 40, 61-66.

Li, J.; Li, D. F.; Xing, J. J.; Cheng, Z. B.; Lai, C. H., 2006: Effects of $\beta$-glucan extracted from Saccharomyces cerevisiae on growth performance, and immunological and somatotropic responses of pigs challenged with Escherichia coli lipopolysaccharide. Journal of Animal Science 84, 2374-2381.

Li, P.; Wen, Q.; Gatlin, D. M., 2009: Dosedependent influences of dietary beta1,3-glucan on innate immunity and disease resistance of hybrid striped bass Morone chrysops $\mathrm{x}$ Morone saxatilis. Aquaculture Research 40, 1578-1584.

Lin, S.; Pan, Y.; Luo, L.; Luo, L., 2011 : Effects of dietary $\beta$-1,3-glucan, chitosan or raffinose on the growth, innate immunity and resistance of koi (Cyprinus carpio koi). Fish and Shellfish Immunology 31, 788-794.

Mayer, L., 2003: Mucosal Immunity. Pediatrics 111, 1595-1600.

Misra, C. K.; Das, B. K.; Mukherjee, S. C.; Pattnaik, P., 2006: Effect of long term administration of dietary beta-glucan on immunity, growth and survival of Labeo rohita fingerlings. Aquaculture 255, 82 94.

Morales-López, R.; Auclair, E.; García, F.; Esteve-Garcia, E.; Brufau, J., 2009: Use of yeast cell walls; $\beta$-1, 3/1, 6-glucans; and mannoproteins in broiler chicken diets. Poultry Science 88, 601-607.

Morales-López, R.; Auclair, E.; Van Immerseel, F.; Ducatelle, R.; García, F.; Brufau, J., 2010: Effects of different yeast cell wall supplements added to maize- or wheat-based diets for broiler chickens. British Poultry Science 51, 399408.

Ngamkala, S.; Futami, K.; Endo, M.; Maita, M.; Katagiri, T., 2010: Immunological effects of glucan and Lactobacillus rhamnosus GG, a probiotic bacterium, on Nile tilapia Oreochromis niloticus intestine with oral Aeromonas challenges. Fisheries Science 76, 833-840.

Nikl, L.; Evelyn, T. P. T.; Albright, L. J., 1993: Trials with an orally and immersion-administered beta-1,3 glucan as an immunoprophylactic against Aeromonas salmonicida in juvenile chinook salmon Oncorhynchus tshawytscha. Diseases of Aquatic Organisms 17, 191-196.

NRC 2011: Nutrient Requirements of Fish and Shrimp. The National Academies Press, Washington DC.

Rice, P. J.; Adams, E. L.; Ozment-Skelton, T.; Gonzalez, A. J.; Goldman, M. P.; Lockhart, B. E.; Barker, L. A.; Breuel, K. F.; DePonti, W. K.; Kalbfleisch, J. H.; Ensley, H. E.; Brown, G. D.; Gordon, S.; Williams, D. L., 2005: Oral delivery and gastrointestinal absorption of soluble glucans stimulate increased resistance to infectious challenge. Journal of Pharmacology and Experimental Therapeutics $\mathbf{3 1 4}$, 1079-1086.

Rowley, A. F.; Hunt, T. C.; Page, M.; Mainwaring, G., 1988: Fish. In: A. F. Rowley, N. A. Ratcliffe (eds), Vertebrate Blood Cells. Cambridge University Press, Cambridge, pp. 19-127.

Schütt, D. A.; Lehmann, J.; Goerlich, R.; Hamers, R., 1997: Haematology of swordtail, Xiphophorus helleri. I: blood parameters and light microscopy of blood cells. Journal of Applied Ichthyology 13, 83-89.

Shelby, R. A.; Lim, C.; Yildirim-Aksoy, M.; Welker, T. L.; Klesius, P. H., 2009: Effects of yeast oligosaccharide diet supplements on growth and disease resistance in juvenile Nile Tilapia, Oreochromis niloticus. Journal of Applied Aquaculture 21, 61-71.

Shen, J.; Ren, H.; Tomiyama-Miyaji, C.; Suga, Y.; Suga, T.; Kuwano, Y.; Iiai, T.; Hatakeyama, K.; Abo, T., 2007: Potentiation of intestinal immunity by micellary mushroom extracts. Biomedical Research 28, 71-77.

Shephard, K. L., 1994: Functions for fish mucus. Reviews in Fish Biology and Fisheries 4, 401-429.
Shi, C.; Pamer, E. G., 2011: Monocyte recruitment during infection and inflammation. Nature Reviews Immunology 11, 762-774.

Siwicki, A. K.; Anderson, D. P.; Rumsey, G. L., 1994: Dietary intake of immunostimulants by rainbow trout affects non-specific immunity and protection against furunculosis. Veterinary Immunology and Immunopathology 41, 125-139.

Siwicki, A. K.; Zakes, Z.; Terech-Majewska, E.; Kazun, K.; Lepa, A.; Glabski, E., 2010: Dietary Macrogard reduces Aeromonas hydrophila mortality in tench (Tinca tinca) through the activation of cellular and humoral defence mechanisms. Reviews in Fish Biology and Fisheries 20, 435-439.

Torrecillas, S.; Makol, A.; Caballero, M. J.; Montero, D.; Robaina, L.; Real, F.;

Sweetman, J.; Tort, L.; Izquierdo, M. S., 2007: Immune stimulation and improved infection resistance in European sea bass (Dicentrarchus labrax) fed mannan oligosaccharides. Fish $\theta$ Shellfish Immunology 23, 969-981.

Trinder, P., 1969: Determination of blood glucose using an oxidase-peroxidase system with a non-carcinogenic chromogen. Journal of Clinical Pathology 22, 158-161.

Tsukada, C.; Yokoyama, H.; Miyaji, C.; Ishimoto, Y.; Kawamura, H.; Abo, T., 2003: Immunopotentiation of intraepithelial lymphocytes in the intestine by oral administrations of $\beta$-glucan. Cellular Immunology 22 1, 1-5.

Welker, T. L.; Lim, C.; Yildirim-Aksoy, M.; Shelby, R.; Klesius, P. H., 2007: Immune response and resistance to stress and Edwardsiella ictaluri challenge in channel catfish, Ictalurus punctatus, fed diets containing commercial wholecell yeast or yeast subcomponents. Journal of the World Aquaculture Society $\mathbf{3 8}$, 24-35.

Zekovic, D. B.; Kwiatkowski, S.; Vrvic, M. M.; Jakovljevic, D.; Moran, C. A., 2005: Natural and modified (1-3)-beta-D-glucans in health promotion and disease alleviation. Critical Reviews in Biotechnology 25, 205-230.

Zhu, H.; Liu, H.; Yan, J.; Wang, R.; Liu, L., 2012: Effect of yeast polysaccharide on some hematologic parameter and gut morphology in channel catfish (Ictalurus punctatus). Fish Physiology and Biochemistry 38, 1441-1447. 